OPEN ACCESS

Edited by:

Ivo Bendix,

Essen University Hospital, Germany

Reviewed by:

Beth J. Allison,

Hudson Institute of Medical Research,

Australia

Gerard Louis Breart,

INSERM U1153 Centre de Recherche

Épidémiologie et Statistique Sorbonne

Paris Cité, France

*Correspondence:

Olivier Baud

olivier.baud@hcuge.ch

Specialty section:

This article was submitted to

Reproduction

a section of the journa

Frontiers in Endocrinology

Received: 26 November 2018 Accepted: 04 March 2019 Published: 26 March 2019

Citation:

Baud O and Berkane N (2019)

Hormonal Changes Associated With

Intra-Uterine Growth Restriction:

Impact on the Developing Brain and

Future Neurodevelopment.

Front. Endocrinol. 10:179.

doi: 10.3389/fendo.2019.00179

\section{Hormonal Changes Associated With Intra-Uterine Growth Restriction: Impact on the Developing Brain and Future Neurodevelopment}

\author{
Olivier Baud ${ }^{1,2 *}$ and Nadia Berkane ${ }^{3}$ \\ ${ }^{1}$ Division of Neonatology and Pediatric Intensive Care, Department of Women-Children-Teenagers, University Hospitals \\ Geneva, Geneva, Switzerland, ${ }^{2}$ Inserm U1141, Sorbonne, Paris Diderot University, Paris, France, ${ }^{3}$ Division of Obstetrics and \\ Gynecology, Department of Women-Children-Teenagers, University Hospitals Geneva, Geneva, Switzerland
}

The environment in which a fetus develops is not only important for its growth and maturation but also for its long-term postnatal health and neurodevelopment. Several hormones including glucocorticosteroids, estrogens and progesterone, insulin growth factor and thyroid hormones, carefully regulate the growth of the fetus and its metabolism during pregnancy by controlling the supply of nutrients crossing the placenta. In addition to fetal synthesis, hormones regulating fetal growth are also expressed and regulated in the placenta, and they play a key role in the vulnerability of the developing brain and its maturation. This review summarizes the current understanding and evidence regarding the involvement of hormonal dysregulation associated with intra-uterine growth restriction and its consequences on brain development.

Keywords: intra-uterine growth restriction, brain development, glucocorticoids, neurosteroids, insulin growth factor, thyroid hormones

\section{FETAL GROWTH RESTRICTION, BRAIN DEVELOPMENT, AND HORMONES}

Fetal growth depends on several factors of maternal, fetal and placental origin, in particular genetic background, nutrients and oxygen supply to the fetus, maternal nutrition and various growth factors and hormones (1). Suboptimal fetal growth is likely to be a key factor of disruption in brain development and many neurodevelopmental disorders of motor and cognitive dysfunction have their origins in the antenatal period $(2,3)$. Specifically, intra-uterine growth restriction (IUGR), defined as the inability of a fetus to reach its genetically determined size is closely linked to neurodevelopmental deficits. Indeed, infants exposed to IUGR conditions are at high risk not only for neonatal death and cerebral palsy (4), but also for other neurodevelopmental morbidities including mental retardation, a wide spectrum of learning disabilities and developmental behavioral disorders associated with the onset of neuropsychiatric disorders later in life (5-7). Several of these neurodevelopmental impairments are associated not only with deleterious effect of brain undergrowth but also with IUGR-related injury of the developing brain. Magnetic resonance imaging (MRI) has clearly revealed alterations of brain development in growth-restricted infants, involving both white and gray matter $(8,9)$ and including altered neural circuitry identified by diffusion MRI connectomics $(10,11)$ that correlate with functional cognitive, motor, and psychiatric deficits later in life $(12,13)$. 
Hormonal balance has a crucial role in fetal growth and maturation, parturition, neonatal adaptation, and brain development (14). Hormones act as maturational and nutritional signals controlling tissue development and differentiation and closely interact with the in utero environment. Imbalance between hormones due to placental dysfunction or antenatal chronic stress conditions don't only impair fetal maturation and growth but could also induce obstetrical, perinatal and neonatal complications including cesarean section, perinatal asphyxia, respiratory distress syndrome, abnormal glycemic regulation or inappropriate adrenal function, and hypothalamus pituitary axis (HPA) responsiveness (5).

This review recapitulates state-of-the art data based on a search in the PubMed library in English for the key words "intra-uterine growth restriction," "hormones," and "brain development." The last search was done in October 2018. No restriction of year and authors were applied and review papers were used as references only for the general concepts. We identified 6 dysregulated hormones in case of IUGR, as a cause or as a result, closely related to brain development and future neurobehavioral outcomes, including glucocorticoids and oxytocin, estrogens and progesterone, insulin growth factor, and thyroid hormones.

\section{FETAL GROWTH RESTRICTION AND CHRONIC EXPOSURE TO ENDOGENOUS GLUCOCORTICOSTEROIDS}

\section{Fetal Growth Restriction, Chronic Antenatal Stress, and Glucocorticoid Exposure}

Glucocorticoids (GCs) are key mediators of stress responses involved during fetal development in the regulation of fetal growth and maturation of fetal tissues and organs $(15,16)$. Experimental and clinical evidence indicates that increased exposure of the fetus to GCs is associated with adverse outcomes including IUGR (17), postnatal hypertension, and cardiovascular disease $(18,19)$, postnatal glucose intolerance, increased postnatal activity in the HPA axis (20), and interference with fetal brain development $(21,22)$. Conversely, placental vascular diseases leading to IUGR were found to be associated with higher plasma cortisol and lower ACTH levels compared to eutrophic fetuses (23).

Besides high concentrations of GCs observed in pregnancies complicated by IUGR, their biological effects are dependent on glucocorticoid receptors (GR), mineralocorticoid receptors, and 1 beta-hydroxysteroid dehydrogenase $1 / 2(11 \beta-H S D 1 / 2)$ whose expression varies over time during the antenatal period. Speirs et al. demonstrated critical periods of GC sensitivity related to changes in the expression of these molecules during antenatal development in the mouse (24). Using in situ hybridization they showed that GR mRNA levels were very low at embryonic day (E9.5) in the fetus but not in the placenta, and then variably rose during gestation in several tissues, including the central nervous system (CNS). In humans, both GR and the MR are highly expressed in the hippocampus from 24 weeks of gestation (25).
Fetal $11 \beta$-HSD1 mRNA expression, which could enhance GC levels locally was detected at low levels in a few brain regions, including the hippocampus only after E16.5 in mice (24). In sheep, a specific increase in the expression of $11 \beta$-HSD1 mRNA in growth-restricted fetuses in late gestation has been reported (26). In the rat, placental $11 \beta$-HSD2 is considered as a "barrier" to endogenous GCs and genetic mutations of this enzyme were found to be associated with low birthweights (27). In humans, the $11 \beta$-HSD2 gene mutation also produces IUGR which is associated with reduced placental activity of this enzyme also highly expressed in the developing brain (28). Altogether, these data, both in animals and in humans, strongly suggest that the effects of high circulating cortisol levels associated with IUGR could be potentiated by specific changes in gene expression involved in their biological response in many tissues including CNS.

\section{Glucocorticoids, Developing Brain, and Microglia Phenotypes}

In humans, GCs regulate several developmental processes in the CNS, including hippocampal neurogenesis with variable effects on proliferation of progenitor cells, neurogenesis and astrogliogenesis in response to either low or high concentrations of cortisol (29). Low cortisol was found to increase proliferation and differentiation of progenitors into S100beta-positive astrocytes, and decrease neurogenesis. High cortisol was found to decrease proliferation and differentiation into neuronal cells without regulating astrogliogenesis. Inappropriate exposure to high levels of GCs early in pregnancy could therefore interfere with overall brain maturation. This programming effect of endogenous GCs affecting notably the HPA axis has been related to gene methylation and histone modifications associated with IUGR $(30,31)$ and can lead to long-lasting effects on the developing brain (32). IUGR also has sex-specific, persistent effects on hippocampal GR expression and its variants, a mechanism involved in HPA axis reprogramming, mostly in males (30).

GCs confer anti-inflammatory and immunosuppressive effects but are also able to potentiate, at high concentrations, inflammatory responses both at central and peripheral levels (33). In a model of restraint prenatal stress associated with higher levels of corticosterone investigated in juvenile and adult rats, a shift of the immune response toward a pro-inflammatory phenotype has been observed in adult rats (34). The change of GC receptor expression or function induced by IUGR could also change the microglia response toward pro-inflammatory insults associated with intensive care of growth-restricted infants, according to a multiple hit concept (35).

Extensive literature has demonstrated that chronic stress and GC exposure can impair the developing brain facing a large variety of insults, including hypoxia-ischemia, hypoglycemia, oxygen radical accumulation, all conditions potentially observed associated to IUGR (36). In preclinical models, IUGR-associated brain damage is usually associated with neuro-inflammation (5, 37-39), a key feature related to exacerbated activation of microglia, the resident macrophages of the CNS, able to 
sensitize the developing brain to a secondary insult $(40,41)$. Microglial cells can acquire distinct phenotypes in response to perinatal stimuli that allow them to either disrupt developmental processes, i.e., myelination, synaptic pruning or axonal growth, or support repair, and regeneration. These diverse roles make microglia critical modulators of brain injury and GC exposure which are able to modulate microglial phenotype both in the developing and mature brain (42-45). In the developing brain, Gómez-González et al. showed that exposure to prenatal stress alters microglia maturation leading to an imbalance between immature and ramified microglia 1 day after birth in rat (46), and increased microglial activation in the hippocampus in juvenile animals $(47,48)$.

\section{Balance Between GCs and Oxytocin}

Oxytocin (OXT), an essential hormone during the perinatal period and parturition, is a neuropeptide released by the paraventricular nucleus and by the supraoptic nucleus of the hypothalamus, which is also known to be balanced against GCs. Indeed, studies carried out in rodents and in humans showed a close link between HPA axis activity and OXT release. OXT is also implicated in autism (49-51) and in the down-regulation of the central inflammatory response to injury in the mature brain (52, 53). In the developing brain, an association between IUGR, low expression of OXT and neuroinflammation, leading to defective myelination and abnormal brain function has been recently reported (54). Pharmacological treatment using carbetocin, a brain permeable long-lasting OXT receptor (OXTR) agonist, was found to be associated with a significant reduction of microglial activation and provided long-term neuroprotection. OTX also alleviated the HPA axis activation reducing GC release $(55,56)$, supporting the hypothesis of indirect anti-inflammatory action of OXT. These findings make OXT a promising candidate for neuroprotection, in particular in the context of IUGR.

\section{SEX STEROID HORMONES}

\section{Sex Steroids in Human Pregnancy and Placenta}

Estradiol (E2) and progesterone (P4) are highly expressed during pregnancy (57). Sex steroids are excreted by syncitiotrophoblasts into the intervillous chambers, entering the maternal circulation, and also the fetal vessels after crossing layers of cytotrophoblasts and stromal cells. While fetal circulating E2 and P4 are mainly of placental origin, hormonal concentrations differ between maternal and fetal circulation (58), implying that some of these hormones are converted in the villi $(59,60) .17 \beta$-hydroxysteroid dehydrogenase-2 (HSD17 $\beta 2$ ) converts E2, testosterone and $\Delta 4$ androstenedione ( $\Delta 4$-dione) into estrone (E1), P4, and $20 \alpha$ dihydroprogesterone, respectively $(61,62)$. These conversions could be involved in a protective effect from excessive fetal feminization or virilization, but could also play other roles (63). In primary culture of rat hippocampal neurons, it has been shown that E2 confers protection against excitotoxic-induced cell death (64), and some E2 metabolites have various effects on fetal brain development through their receptors by promoting neurite outgrowth, myelination, and synaptogenesis $(3,65,66)$ as well as neuroprotective roles (67). P4 is already used as a treatment in human adult traumatic brain injury (68).

Interestingly, recent human studies have suggested that maternal serum concentrations of E2, P4 and some of their metabolites are modified during human pregnancy complicated by preeclampsia and/or IUGR with lower placental aromatization and E2 levels and higher P4 inactivation $(20 \alpha$ hydroxylation) (69-75).

While growing evidence demonstrates that steroidogenic enzymes are highly expressed in the CNS, below, we describe data suggesting that changes in P4 and E2 induced by IUGR could have an impact on fetal brain development and adaptation to hypoxic stress.

\section{Progesterone and Allopregnanolone and the Fetal Brain}

Both in rodents and in humans, a large variety of brain structures (including olfactory bulb, hypothalamus, striatum, hippocampus, cerebral cortex, and cerebellum) and cell types (including glial, Purkinje, and Schwann cells) synthetize P4 (76, 77). Its $3 \alpha, 5 \alpha$-tetrahydroprogesterone (allopregnanolone) metabolite is mainly expressed in the cerebellum of neonatal rats (78). Progesterone receptors are expressed in rats by Purkinje cells and in the cerebellum.

Both P4 and allopregnanolone have a recognized role in neuroprotection (79). P4 has been found to induce inhibition of voltage-gated calcium channels (80) in the rat brain. Allopregnanolone found at high concentrations in maternal (81) and fetal sheep circulation (82) has been shown to have neurotrophic effects on neurons and glial cells $(83,84)$ in the ovine fetal brain (85).

In humans, available studies comparing controls and preeclamptic women reported conflicting results with unchanged, or higher maternal P4 concentrations $(69,74,75)$. Using a reliable gas chromatography/mass spectrometry technique, no difference in maternal blood P4 and allopregnanolone concentrations was reported in women with vascular IUGR with or without preeclampsia compared to normal pregnancy (69). In contrast, in pregnant women with preexisting chronic hypertension, the development of preeclampsia was associated with higher allopregenalone concentrations (75).

In a model of IUGR developed in guinea pigs subjected to partial devascularization of the uterine horns during pregnancy, decreased allopregnanolone concentrations have been observed in fetal plasma and brain $(79,86)$. Moreover, in this model, despite increased expression of progesterone receptors in the brain, myelination was found to be decreased in the hippocampal region (87). Nevertheless, further studies are needed to better assess changes in P4 and its metabolite concentrations and signaling pathways involved in the adaptive response of the fetal brain to stress.

\section{Estradiol}

In rats, estradiol (E2) is synthetized by the hippocampus (88) and cerebellum (89) and potentially by other parts of the brain with some gender differences (90). E2 effects on the 
brain are not yet well understood as both protecting $(64,91)$ and damaging effects $(90,92)$ have been described in primary cultures of rat hippocampal neurons. This hormone has been shown to promote axonal growth notably in cell cultures of fetal rat neurons derived from the ventromedial nucleus of the hypothalamus (93). In the oligodendroglial lineage, E2 also promotes the proliferation of immature oligodendrocytes, their differentiation into myelinating oligodendrocytes, and strongly reduces apoptotic cell death and neuro-inflammation in response to insult (94). On the other hand, as a potent regulator of the depolarizing actions of GABA, E2 can insult fetal brains subjected to hypoxic conditions by increasing the response to excessive GABA release via excess of free intracellular calcium (90).

Aromatase is a key enzyme for estrogen synthesis and several studies suggested a placental aromatase reduced activity in pregnancy with preeclampsia $(70-75,95)$ or with IUGR $(69)$. As placenta is the major source of fetal estrogens, significantly lower maternal concentrations of E2, E1, or E1/ $\Delta 4$-dione were reported in these pregnancies which may affect fetal estrogen levels. It can be hypothesized that during an IUGR pregnancy, a lack of fetal estrogens could disturb brain development. However, to our knowledge, no fetal or neonatal blood estrogen profile has been reported yet. Whether this abnormal placental steroidogenesis might induce changes in the steroid profile in the fetal compartment with potential brain insult remains to be determined. In addition, it is important to keep in mind that the developing brain itself has the capability to synthesize and convert sex steroids adding complexity to the interpretation of blood level data.

Despite these limitations, current evidence increasingly supports that E2, P4, and allopregnanolone play a key role in brain development and might be important modulators of brain vulnerability in the fetus with IUGR.

\section{ROLE OF THE GLUCOSE-INSULIN-INSULIN-LIKE GROWTH FACTOR I (IGF-I) AXIS IN PLACENTAL AND FETAL GROWTH}

\section{Regulation of IGF Signaling in Growth Restricted Fetuses}

The regulation of fetal growth depends not only on the nutrients available to the fetus but also on the regulation of InsulinIGF/IGF binding protein 3 (IGFBP-3) axis $(96,97)$. The IGF factors I and II work together to control fetal growth through changes in size and function of the placenta. IGF-II is important for placental growth and development, and therefore allows more nutrients to reach the fetus. IGF-I acts as a "nutrient sensor" and finely regulates nutrient transfer across the placenta according to both the maternal environment and fetal demand. The production of IGF-I, particularly sensitive to maternal undernutrition and parental imprinting, regulates its signaling through its receptor (98). Disruption of this imprinting causes growth disorders including Beckwith-Wiedemann syndrome, associated with fetal overgrowth, and Silver-Russell syndrome, associated with IUGR (99). Several studies have shown that infants born growth restricted have lower levels of IGF-I, IGFBP3 , and insulin compared to appropriate for gestational age infants (100-102). The IGF system, IGF-I and IGF-II in particular, plays a critical role in fetal and placental growth. Disruption of the IGFI, IGF-II, or IGF-IR gene induces IUGR, whereas disruption of IGF-IIR or overexpression of IGF-II enhances fetal growth (103).

\section{Placenta and IGF Signaling}

Many metabolic adaptations of pregnancy are regulated by placental hormones which undergo dramatic changes during gestation including placental estrogen and progesterone (104). Placental hormone expression is supposed to interact with fetal growth through polymorphic or epigenetic regulation of placental growth hormone (PGH) and human chorionic somatomammotropin (CSH) expression could alter the expression of other critical hormones including insulin or IGF-I (105). However, definitive evidence supporting that specific placental hormones are required for normal pregnancy and fetal growth is currently lacking. It is possible that other hormones of maternal origin, such as pituitary GH and/or prolactin, might partially compensate for reduced expression of placental hormones.

\section{Defective IGF Signaling and Neurodevelopment}

Abnormal fetal growth could also be associated with medicallyinduced preterm delivery (106). Low IGF-1 levels in very preterm infants and IUGR neonates were reported to be associated with high risk factor for adverse outcomes including chronic lung disease and retinopathy of prematurity. IGF-1 also plays crucial roles in the development and maturation (107) of the CNS with potent effects on cellular neuroplasticity, learning and memory, and confers neuroprotection following brain injury. IGF-1 acts at several sites to induce cellular plasticity through its receptor IGF-1R in neuronal and nonneuronal cells. IGF-1R is known to induce cellular plasticity by acting on glutamate receptors including AMPA/kaïnate-R, NMDA-R, calcium channels, and neurotransmitter release (108). Abnormal excitatory synaptic transmission observed in genetic diseases associated with behavioral disorders can be corrected by restoring SHANK3 expression or by treating neurons with IGF-1 (109). Regarding microglial activation, a major factor of brain injury, aging-related decrease in IGF-1 may contribute to the defective switch of microglia toward immunomodulatory and repair phenotype (110). During development, the IGF-1 level in cerebral spinal fluid is high, consistently with its important role in brain development, neuronal growth promotion, cellular proliferation, and differentiation (111). Finally, IGF-1 induces anti-inflammatory properties both in the developing and mature brain related to down-regulation of brain cytokine expression (112-114). Studies investigating the effects of intra-nasal IGF-1 demonstrated neuroprotection in models of LPS-induced white matter injury in the developing rat brain (115), cerebral hypoxicischemic injury $(116,117)$, and other neurodegenerative damages (118), probably through the phophatidylinositol-3 kinase/Akt pathway (119). However, the causality between low IGF-1 
levels and neuroinflammation associated with IUGR remains to be confirmed.

\section{THYROID HORMONES}

Thyroid hormones are essential for fetal brain development and maturation. Severe but also mild or subclinical neonatal hypothyroidism has been associated with neurodevelopmental impairment (120-124). However, all neonates with subclinical or mild hypothyroidism are not identified by newborn screening programs (Guthrie test). Factors associated with neonatal hypothyroidism include prematurity and IUGR $(125,126)$. IUGR and/or preeclampsia can be the consequences of placental insufficiency associated with overexpression of sFlt-1 (soluble fms-like tyrosine kinase-1) a soluble form of the vascular endothelial growth factor- type 1 (VEGFR-1) (127), several weeks before the beginning of maternal clinical signs (128). sFlt1 has anti-mitogenic properties on endothelial cells (129) by trapping VEGF and placental growth factor (PlGF) leading to hypertension and proteinuria $(127,130)$. When IUGR occurs in human, higher sFlt-1 or sFlt-1/PlGF ratio concentrations in maternal blood have also been observed compared to the control group $(131,132)$. A nested case control study showed that preeclampsia predisposes to reduced maternal thyroid function (transient or permanent) (133) as others report (134). This thyroid insufficiency seems to be mediated by sFlt-1 which impairs fenestrated capillary endothelium present in endocrine glands (135). By disrupting VEGF/VEGF-R signaling in adult mice, Kamba et al. showed capillary regression in different organs, the amount of regression was dose- and organdependent with the highest effect in thyroid (135). Recovery of thyroid capillary density has been observed within 2 weeks after cessation of treatment. Since sFlt- 1 crosses the placenta, an impact of fetal thyroid function could also be suspected with risk of subsequent neurodevelopmental impairment. Cord blood sFlt1 concentrations have been found to be inversely correlated to birthweight (136) and free T4 and positively correlated with thyroid stimulating hormone (TSH) (137).

\section{REFERENCES}

1. Burton GJ, Jauniaux E. Pathophysiology of placental-derived fetal growth restriction. Am J Obstet Gynecol. (2018) 218:S745-61. doi: 10.1016/j.ajog.2017.11.577

2. Levine TA, Grunau RE, McAuliffe FM, Pinnamaneni R, Foran A, Alderdice FA. Early childhood neurodevelopment after intrauterine growth restriction: a systematic review. Pediatrics. (2015) 135:126-41. doi: 10.1542/peds.2014-1143

3. Miranda A, Sousa N. Maternal hormonal milieu influence on fetal brain development. Brain Behav. (2018) 8:e00920. doi: 10.1002/brb3.920

4. Jarvis S, Glinianaia SV, Torrioli MG, Platt MJ, Miceli M, Jouk PS, et al. Cerebral palsy and intrauterine growth in single births: European collaborative study. Lancet. (2003) 362:1106-11. doi: 10.1016/S0140-6736(03)14466-2

5. Colella M, Frerot A, Novais ARB, Baud O. Neonatal and long-term consequences of fetal growth restriction. Curr Pediatr Rev. (2018) 14:212-8. doi: $10.2174 / 1573396314666180712114531$
However, conflicting findings have been reported regarding the effect of IUGR on fetal serum concentration of thyroid hormones. In a series of 49 growth-restricted fetuses who had cordocentesis during pregnancy, higher concentrations of TSH and lower concentrations of free T4 have been found compared to fetuses with appropriate growth for gestational age, and changes in TSH concentrations were correlated to fetal hypoxia and academia (138). In contrast, others reported unchanged or low TSH levels in IUGR cord blood compared to controls (139-142). Variability in fetal exposure to sFlt1 could be involved in $\mathrm{TSH}$ regulation and may partly explain these conflicting findings.

In summary, IUGR leads to neuropathological consequences for the developing brain with heterogeneous features and longterm neurocognitive and behavioral consequences $(5,143)$. Many factors contribute to the vulnerability of the developing brain, including age of delivery, severity of in utero compromise, comorbidities occurring during the perinatal period, complications associated with medically-induced preterm delivery. Changes in several hormones strongly involved in the regulation of brain development and maturation are likely to play a key role. More research is needed to better understand these crosstalks.

\section{AUTHOR CONTRIBUTIONS}

$\mathrm{OB}$ and NB did the literature review and collectively analyzed articles selected in this review paper. $\mathrm{OB}$ wrote paragraphs related to introduction, glucocorticoids, oxytocin, and IGF1. NB wrote paragraphs related to sex steroids and thyroid hormones.

\section{FUNDING}

This work was supported by Fondation de l'Avenir.

\section{ACKNOWLEDGMENTS}

The authors thank Audrey Toulotte-Aebi for editing the manuscript.

6. Guellec I, Marret S, Baud O, Cambonie G, Lapillonne A, Roze JC, et al. Intrauterine growth restriction, head size at birth, and outcome in very preterm infants. J Pediatr. (2015) 167:975-81 e2. doi: 10.1016/j.jpeds.2015.08.025

7. Wiles NJ, Peters TJ, Heron J, Gunnell D, Emond A, Lewis G. Fetal growth and childhood behavioral problems: results from the ALSPAC cohort. Am J Epidemiol. (2006) 163:829-37. doi: 10.1093/aje/kwj108

8. Padilla N, Junque C, Figueras F, Sanz-Cortes M, Bargallo N, Arranz A, et al. Differential vulnerability of gray matter and white matter to intrauterine growth restriction in preterm infants at 12 months corrected age. Brain Res. (2014) 1545:1-11. doi: 10.1016/j.brainres.2013.12.007

9. Dubois J, Benders M, Borradori-Tolsa C, Cachia A, Lazeyras F, Ha-Vinh Leuchter R, et al. Primary cortical folding in the human newborn: an early marker of later functional development. Brain. (2008) 131:2028-41. doi: 10.1093/brain/awn137

10. Batalle D, Eixarch E, Figueras F, Munoz-Moreno E, Bargallo N, Illa $\mathrm{M}$, et al. Altered small-world topology of structural brain networks in infants with intrauterine growth restriction and its association 
with later neurodevelopmental outcome. Neuroimage. (2012) 60:1352-66. doi: 10.1016/j.neuroimage.2012.01.059

11. Fischi-Gomez E, Vasung L, Meskaldji DE, Lazeyras F, Borradori-Tolsa C, Hagmann P, et al. Structural brain connectivity in school-age preterm infants provides evidence for impaired networks relevant for higher order cognitive skills and social cognition. Cereb Cortex. (2015) 25:2793-805. doi: 10.1093/cercor/bhu073

12. Tolsa CB, Zimine S, Warfield SK, Freschi M, Sancho Rossignol A, Lazeyras F, et al. Early alteration of structural and functional brain development in premature infants born with intrauterine growth restriction. Pediatr Res. (2004) 56:132-8. doi: 10.1203/01.PDR.0000128983.54614.7E

13. Egana-Ugrinovic G, Sanz-Cortes M, Figueras F, Couve-Perez C, Gratacos E. Fetal MRI insular cortical morphometry and its association with neurobehavior in late-onset small-for-gestational-age fetuses. Ultrasound Obstet Gynecol. (2014) 44:322-9. doi: 10.1002/uog.13360

14. Murphy VE, Smith R, Giles WB, Clifton VL. Endocrine regulation of human fetal growth: the role of the mother, placenta, and fetus. Endocr Rev. (2006) 27:141-69. doi: 10.1210/er.2005-0011

15. Lesage J, Blondeau B, Grino M, Breant B, Dupouy JP. Maternal undernutrition during late gestation induces fetal overexposure to glucocorticoids and intrauterine growth retardation, and disturbs the hypothalamo-pituitary adrenal axis in the newborn rat. Endocrinology. (2001) 142:1692-702. doi: 10.1210/endo.142.5.8139

16. Sutherland AE, Crossley KJ, Allison BJ, Jenkin G, Wallace EM, Miller SL. The effects of intrauterine growth restriction and antenatal glucocorticoids on ovine fetal lung development. Pediatr Res. (2012) 71:689-96. doi: 10.1038/pr.2012.19

17. Bloom SL, Sheffield JS, McIntire DD, Leveno KJ. Antenatal dexamethasone and decreased birth weight. Obstet Gynecol. (2001) 97:485-90. doi: 10.1097/00006250-200104000-00001

18. Benediktsson R, Lindsay RS, Noble J, Seckl JR, Edwards CR. Glucocorticoid exposure in utero: new model for adult hypertension. Lancet. (1993) 341:339-41. doi: 10.1016/0140-6736(93)90138-7

19. Barker DJ. Fetal nutrition and cardiovascular disease in later life. Br Med Bull. (1997) 53:96-108. doi: 10.1093/oxfordjournals.bmb.a011609

20. de Vries A, Holmes MC, Heijnis A, Seier JV, Heerden J, Louw J, et al. Prenatal dexamethasone exposure induces changes in nonhuman primate offspring cardiometabolic and hypothalamic-pituitary-adrenal axis function. J Clin Invest. (2007) 117:1058-67. doi: 10.1172/JCI30982

21. Matthews SG. Antenatal glucocorticoids and programming of the developing CNS. Pediatr Res. (2000) 47:291-300. doi: 10.1203/00006450-200003000-00003

22. Uno H, Eisele S, Sakai A, Shelton S, Baker E, DeJesus O, et al. Neurotoxicity of glucocorticoids in the primate brain. Horm Behav. (1994) 28:336-48. doi: 10.1006/hbeh.1994.1030

23. Economides DL, Nicolaides KH, Linton EA, Perry LA, Chard T. Plasma cortisol and adrenocorticotropin in appropriate and small for gestational age fetuses. Fetal Ther. (1988) 3:158-64. doi: 10.1159/000263348

24. Speirs HJ, Seckl JR, Brown RW. Ontogeny of glucocorticoid receptor and 11beta-hydroxysteroid dehydrogenase type-1 gene expression identifies potential critical periods of glucocorticoid susceptibility during development. J Endocrinol. (2004) 181:105-16. doi: 10.1677/joe.0. 1810105

25. Noorlander CW, De Graan PN, Middeldorp J, Van Beers JJ, Visser GH. Ontogeny of hippocampal corticosteroid receptors: effects of antenatal glucocorticoids in human and mouse. J Comp Neurol. (2006) 499:924-32. doi: 10.1002/cne.21162

26. McMillen IC, Warnes KE, Adams MB, Robinson JS, Owens JA, Coulter CL. Impact of restriction of placental and fetal growth on expression of 11 betahydroxysteroid dehydrogenase type 1 and type 2 messenger ribonucleic acid in the liver, kidney, and adrenal of the sheep fetus. Endocrinology. (2000) 141:539-43. doi: 10.1210/endo.141.2.7338

27. Seckl JR, Cleasby M, Nyirenda MJ. Glucocorticoids, 11beta-hydroxysteroid dehydrogenase, and fetal programming. Kidney Int. (2000) 57:1412-7. doi: 10.1046/j.1523-1755.2000.00984.x

28. Wyrwoll CS, Holmes MC, Seckl JR. 11beta-hydroxysteroid dehydrogenases and the brain: from zero to hero, a decade of progress. Front Neuroendocrinol. (2011) 32:265-86. doi: 10.1016/j.yfrne.2010.12.001
29. Anacker C, Cattaneo A, Luoni A, Musaelyan K, Zunszain PA, Milanesi E, et al. Glucocorticoid-related molecular signaling pathways regulating hippocampal neurogenesis. Neuropsychopharmacology. (2013) 38:872-83. doi: $10.1038 / \mathrm{npp} .2012 .253$

30. Ke X, Schober ME, McKnight RA, O'Grady S, Caprau D, Yu X, et al. Intrauterine growth retardation affects expression and epigenetic characteristics of the rat hippocampal glucocorticoid receptor gene. Physiol Genomics. (2010) 42:177-89. doi: 10.1152/physiolgenomics.00201. 2009

31. Filiberto AC, Maccani MA, Koestler D, Wilhelm-Benartzi C, AvissarWhiting M, Banister CE, et al. Birthweight is associated with DNA promoter methylation of the glucocorticoid receptor in human placenta. Epigenetics. (2011) 6:566-72. doi: 10.4161/epi.6.5.15236

32. Wood CE. Development and programming of the hypothalamuspituitary-adrenal axis. Clin Obstet Gynecol. (2013) 56:610-21. doi: $10.1097 /$ GRF.0b013e31829e5b15

33. Yeager MP, Rassias AJ, Pioli PA, Beach ML, Wardwell K, Collins JE, et al. Pretreatment with stress cortisol enhances the human systemic inflammatory response to bacterial endotoxin. Crit Care Med. (2009) 37:2727-32. doi: 10.1097/CCM.0b013e3181a592b3

34. Vanbesien-Mailliot CC, Wolowczuk I, Mairesse J, Viltart O, Delacre M, Khalife J, et al. Prenatal stress has pro-inflammatory consequences on the immune system in adult rats. Psychoneuroendocrinology. (2007) 32:114-24. doi: 10.1016/j.psyneuen.2006.11.005

35. Leviton A, Fichorova RN, O'Shea TM, Kuban K, Paneth N, Dammann O, et al. Two-hit model of brain damage in the very preterm newborn: small for gestational age and postnatal systemic inflammation. Pediatr Res. (2013) 73:362-70. doi: 10.1038/pr.2012.188

36. Sorrells SF, Sapolsky RM. An inflammatory review of glucocorticoid actions in the CNS. Brain Behav Immun. (2007) 21:259-72. doi: 10.1016/j.bbi.2006.11.006

37. Baud O, Daire JL, Dalmaz Y, Fontaine RH, Krueger RC, Sebag G, et al. Gestational hypoxia induces white matter damage in neonatal rats: a new model of periventricular leukomalacia. Brain Pathol. (2004) 14:1-10. doi: 10.1111/j.1750-3639.2004.tb00492.x

38. Olivier P, Baud O, Evrard P, Gressens P, Verney C. Prenatal ischemia and white matter damage in rats. J Neuropathol Exp Neurol. (2005) 64:998-1006. doi: 10.1097/01.jnen.0000187052.81889.57

39. Olivier P, Baud O, Bouslama M, Evrard P, Gressens P, Verney C. Moderate growth restriction: deleterious and protective effects on white matter damage. Neurobiol Dis. (2007) 26:253-63. doi: 10.1016/j.nbd.2007.01.001

40. Rideau Batista Novais A, Pham H, Van de Looij Y, Bernal M, Mairesse J, Zana-Taieb E, et al. Transcriptomic regulations in oligodendroglial and microglial cells related to brain damage following fetal growth restriction. Glia. (2016) 64:2306-20. doi: 10.1002/glia.23079

41. Fleiss B, Gressens P. Tertiary mechanisms of brain damage: a new hope for treatment of cerebral palsy? Lancet Neurol. (2012) 11:556-66. doi: 10.1016/S1474-4422(12)70058-3

42. Frank MG, Hershman SA, Weber MD, Watkins LR, Maier SF. Chronic exposure to exogenous glucocorticoids primes microglia to pro-inflammatory stimuli and induces NLRP3 mRNA in the hippocampus. Psychoneuroendocrinology. (2014) 40:191-200. doi: 10.1016/j.psyneuen.2013.11.006

43. Nair A, Bonneau RH. Stress-induced elevation of glucocorticoids increases microglia proliferation through NMDA receptor activation. $J$ Neuroimmunol. (2006) 171:72-85. doi: 10.1016/j.jneuroim.2005.09.012

44. Wu CH, Chien HF, Chang CY, Chen SH, Huang YS. Response of amoeboid and differentiating ramified microglia to glucocorticoids in postnatal rats: a lectin histochemical and ultrastructural study. Neurosci Res. (2001) 40:23544. doi: 10.1016/S0168-0102(01)00231-0

45. Tentillier N, Etzerodt A, Olesen MN, Rizalar FS, Jacobsen J, Bender $\mathrm{D}$, et al. Anti-inflammatory modulation of microglia via CD163targeted glucocorticoids protects dopaminergic neurons in the 6-OHDA Parkinson's disease model. J Neurosci. (2016) 36:9375-90. doi: 10.1523/JNEUROSCI.1636-16.2016

46. Gomez-Gonzalez B, Escobar A. Prenatal stress alters microglial development and distribution in postnatal rat brain. Acta Neuropathol. (2010) 119:303-15. doi: 10.1007/s00401-009-0590-4 
47. Roque A, Ochoa-Zarzosa A, Torner L. Maternal separation activates microglial cells and induces an inflammatory response in the hippocampus of male rat pups, independently of hypothalamic and peripheral cytokine levels. Brain Behav Immun. (2016) 55:39-48. doi: 10.1016/j.bbi.2015.09.017

48. Slusarczyk J, Trojan E, Glombik K, Budziszewska B, Kubera M, Lason $\mathrm{W}$, et al. Prenatal stress is a vulnerability factor for altered morphology and biological activity of microglia cells. Front Cell Neurosci. (2015) 9:82. doi: 10.3389/fncel.2015.00082

49. Tyzio R, Nardou R, Ferrari DC, Tsintsadze T, Shahrokhi A, Eftekhari $\mathrm{S}$, et al. Oxytocin-mediated GABA inhibition during delivery attenuates autism pathogenesis in rodent offspring. Science. (2014) 343:675-9. doi: 10.1126/science. 1247190

50. Tyzio R, Cossart R, Khalilov I, Minlebaev M, Hubner CA, Represa A, et al. Maternal oxytocin triggers a transient inhibitory switch in GABA signaling in the fetal brain during delivery. Science. (2006) 314:1788-92. doi: $10.1126 /$ science. 1133212

51. Penagarikano O, Lazaro MT, Lu XH, Gordon A, Dong H, Lam HA, et al. Exogenous and evoked oxytocin restores social behavior in the Cntnap2 mouse model of autism. Sci Transl Med. (2015) 7:271ra8. doi: 10.1126/scitranslmed.3010257

52. Yuan L, Liu S, Bai X, Gao Y, Liu G, Wang X, et al. Oxytocin inhibits lipopolysaccharide-induced inflammation in microglial cells and attenuates microglial activation in lipopolysaccharide-treated mice. J Neuroinflamm. (2016) 13:77. doi: 10.1186/s12974-016-0541-7

53. Zinni M, Colella M, Batista Novais AR, Baud O, Mairesse J. Modulating the oxytocin system during the perinatal period: a new strategy for neuroprotection of the immature brain? Front Neurol. (2018) 9:229. doi: 10.3389/fneur.2018.00229

54. Mairesse J, Zinni M, Pansiot J, Hassan-Abdi R, Demene C, Colella M, et al. Oxytocin receptor agonist reduces perinatal brain damage by targeting microglia. Glia. (2018) 67:345-59. doi: 10.1002/glia.23546

55. Jurek B, Slattery DA, Hiraoka Y, Liu Y, Nishimori K, Aguilera G, et al. Oxytocin regulates stress-induced Crf gene transcription through CREBregulated transcription coactivator 3. J Neurosci. (2015) 35:12248-60. doi: 10.1523/JNEUROSCI.1345-14.2015

56. Windle RJ, Kershaw YM, Shanks N, Wood SA, Lightman SL, Ingram CD. Oxytocin attenuates stress-induced c-fos mRNA expression in specific forebrain regions associated with modulation of hypothalamo-pituitary-adrenal activity. J Neurosci. (2004) 24:2974-82. doi: 10.1523/JNEUROSCI.3432-03.2004

57. Abbassi-Ghanavati M, Greer LG, Cunningham FG. Pregnancy and laboratory studies: a reference table for clinicians. Obstet Gynecol. (2009) 114:1326-31. doi: 10.1097/AOG.0b013e3181c2bde8

58. Hill M, Parizek A, Cibula D, Kancheva R, Jirasek JE, Jirkovska $\mathrm{M}$, et al. Steroid metabolome in fetal and maternal body fluids in human late pregnancy. J Steroid Biochem Mol Biol. (2010) 122:114-32. doi: 10.1016/j.jsbmb.2010.05.007

59. Gurpide E, Marks C, de Ziegler D, Berk PD, Brandes JM. Asymmetric release of estrone and estradiol derived from labeled precursors in perfused human placentas. Am J Obstet Gynecol. (1982) 144:551-5. doi: 10.1016/0002-9378(82)90226-5

60. Drolet R, Simard M, Plante J, Laberge P, Tremblay Y. Human type 2 17 beta-hydroxysteroid dehydrogenase mRNA and protein distribution in placental villi at mid and term pregnancy. Reprod Biol Endocrinol. (2007) 5:30. doi: 10.1186/1477-7827-5-30

61. Blomquist $\mathrm{CH}$. Kinetic analysis of enzymic activities: prediction of multiple forms of 17 beta-hydroxysteroid dehydrogenase. J Steroid Biochem Mol Biol. (1995) 55:515-24. doi: 10.1016/0960-0760(95)00200-6

62. Wu L, Einstein M, Geissler WM, Chan HK, Elliston KO, Andersson S. Expression cloning and characterization of human 17 beta-hydroxysteroid dehydrogenase type 2, a microsomal enzyme possessing 20 alphahydroxysteroid dehydrogenase activity. J Biol Chem. (1993) 268:12964-9.

63. Moghrabi N, Head JR, Andersson S. Cell type-specific expression of 17 betahydroxysteroid dehydrogenase type 2 in human placenta and fetal liver. $J$ Clin Endocrinol Metab. (1997) 82:3872-8.

64. Hilton GD, Nunez JL, Bambrick L, Thompson SM, McCarthy MM. Glutamate-mediated excitotoxicity in neonatal hippocampal neurons is mediated by mGluR-induced release of $\mathrm{Ca}++$ from intracellular stores and is prevented by estradiol. Eur J Neurosci. (2006) 24:3008-16. doi: 10.1111/j.1460-9568.2006.05189.x

65. Garcia-Segura LM, Melcangi RC. Steroids and glial cell function. Glia. (2006) 54:485-98. doi: 10.1002/glia.20404

66. Haraguchi S, Sasahara K, Shikimi H, Honda S, Harada N, Tsutsui K. Estradiol promotes purkinje dendritic growth, spinogenesis, and synaptogenesis during neonatal life by inducing the expression of BDNF. Cerebellum. (2012) 11:416-7. doi: 10.1007/s12311-011-0342-6

67. Xiao Q, Luo Y, Lv F, He Q, Wu H, Chao F, et al. Protective effects of 17beta-estradiol on hippocampal myelinated fibers in ovariectomized middle-aged rats. Neuroscience. (2018) 385:143-53. doi: 10.1016/j.neuroscience.2018.06.006

68. Xiao G, Wei J, Yan W, Wang W, Lu Z. Improved outcomes from the administration of progesterone for patients with acute severe traumatic brain injury: a randomized controlled trial. Crit Care. (2008) 12:R61. doi: $10.1186 /$ cc6887

69. Berkane N, Liere P, Lefevre G, Alfaidy N, Nahed RA, Vincent J, et al. Abnormal steroidogenesis and aromatase activity in preeclampsia. Placenta. (2018) 69:40-9. doi: 10.1016/j.placenta.2018.07.004

70. Hertig A, Liere P, Chabbert-Buffet N, Fort J, Pianos A, Eychenne B, et al. Steroid profiling in preeclamptic women: evidence for aromatase deficiency. Am J Obstet Gynecol. (2010) 203:477 e1-9. doi: 10.1016/j.ajog.2010.06.011

71. Jobe SO, Tyler CT, Magness RR. Aberrant synthesis, metabolism, and plasma accumulation of circulating estrogens and estrogen metabolites in preeclampsia implications for vascular dysfunction. Hypertension. (2013) 61:480-7. doi: 10.1161/HYPERTENSIONAHA.111.201624

72. Bussen S, Bussen D. Influence of the vascular endothelial growth factor on the development of severe pre-eclampsia or HELLP syndrome. Arch Gynecol Obstet. (2011) 284:551-7. doi: 10.1007/s00404-010-1704-X

73. Yin G, Zhu X, Guo C, Yang Y, Han T, Chen L, et al. Differential expression of estradiol and estrogen receptor alpha in severe preeclamptic pregnancies compared with normal pregnancies. Mol Med Rep. (2013) 7:981-5. doi: 10.3892/mmr.2013.1262

74. Walsh SW. Progesterone and estradiol production by normal and preeclamptic placentas. Obstet Gynecol. (1988) 71:222-6.

75. Luisi S, Petraglia F, Benedetto C, Nappi RE, Bernardi F, Fadalti M, et al. Serum allopregnanolone levels in pregnant women: changes during pregnancy, at delivery, and in hypertensive patients. J Clin Endocrinol Metab. (2000) 85:2429-33. doi: 10.1210/jcem.85.7.6675

76. Schumacher M, Hussain R, Gago N, Oudinet JP, Mattern C, Ghoumari AM. Progesterone synthesis in the nervous system: implications for myelination and myelin repair. Front Neurosci. (2012) 6:10. doi: 10.3389/fnins.2012. 00010

77. Tsutsui K. Neurosteroids in the Purkinje cell: biosynthesis, mode of action and functional significance. Mol Neurobiol. (2008) 37:116-25. doi: 10.1007/s12035-008-8024-1

78. Tsutsui K, Ukena K. Neurosteroids in the cerebellar Purkinje neuron and their actions (review). Int J Mol Med. (1999) 4:49-56. doi: 10.3892/ijmm.4.1.49

79. Brunton PJ, Russell JA, Hirst JJ. Allopregnanolone in the brain: protecting pregnancy and birth outcomes. Prog Neurobiol. (2014) 113:106-36. doi: 10.1016/j.pneurobio.2013.08.005

80. Luoma JI, Kelley BG, Mermelstein PG. Progesterone inhibition of voltagegated calcium channels is a potential neuroprotective mechanism against excitotoxicity. Steroids. (2011) 76:845-55. doi: 10.1016/j.steroids.2011. 02.013

81. Pennell KD, Woodin MA, Pennell PB. Quantification of neurosteroids during pregnancy using selective ion monitoring mass spectrometry. Steroids. (2015) 95:24-31. doi: 10.1016/j.steroids.2014.12.007

82. Nguyen PN, Billiards SS, Walker DW, Hirst JJ. Changes in 5alphapregnane steroids and neurosteroidogenic enzyme expression in fetal sheep with umbilicoplacental embolization. Pediatr Res. (2003) 54:840-7. doi: 10.1203/01.PDR.0000088066.47755.36

83. Wang JM. Allopregnanolone and neurogenesis in the nigrostriatal tract. Front Cell Neurosci. (2014) 8:224. doi: 10.3389/fncel.2014.00224

84. Pluchino N, Russo M, Genazzani AR. The fetal brain: role of progesterone and allopregnanolone. Horm Mol Biol Clin Investig. (2016) 27:29-34X. doi: $10.1515 /$ hmbci-2016-0020 
85. Nguyen PN, Billiards SS, Walker DW, Hirst JJ. Changes in 5alpha-pregnane steroids and neurosteroidogenic enzyme expression in the perinatal sheep. Pediatr Res. (2003) 53:956-64. doi: 10.1203/01.PDR.0000064905.64688.10

86. Kelleher MA, Palliser HK, Walker DW, Hirst JJ. Sex-dependent effect of a low neurosteroid environment and intrauterine growth restriction on foetal guinea pig brain development. J Endocrinol. (2011) 208:301-9. doi: 10.1677/JOE-10-0248

87. Palliser HK, Kelleher MA, Tolcos M, Walker DW, Hirst JJ. Effect of postnatal progesterone therapy following preterm birth on neurosteroid concentrations and cerebellar myelination in guinea pigs. J Dev Orig Health Dis. (2015) 6:350-61. doi: 10.1017/S2040174415001075

88. Fester L, Prange-Kiel J, Jarry H, Rune GM. Estrogen synthesis in the hippocampus. Cell Tissue Res. (2011) 345:285-94. doi: 10.1007/s00441-011-1221-7

89. Dean SL, McCarthy MM. Steroids, sex and the cerebellar cortex: implications for human disease. Cerebellum. (2008) 7:38-47. doi: 10.1007/s12311-008-0003-6

90. McCarthy MM. The two faces of estradiol: effects on the developing brain. Neuroscientist. (2009) 15:599-610. doi: 10.1177/1073858409340924

91. Pansiot J, Pham H, Dalous J, Chevenne D, Colella M, Schwendimann L, et al. Glial response to 17 beta-estradiol in neonatal rats with excitotoxic brain injury. Exp Neurol. (2016) 282:56-65. doi: 10.1016/j.expneurol.2016.05.024

92. Nunez JL, McCarthy MM. Resting intracellular calcium concentration, depolarizing Gamma-Aminobutyric Acid and possible role of local estradiol synthesis in the developing male and female hippocampus. Neuroscience. (2009) 158:623-34. doi: 10.1016/j.neuroscience.2008.09.061

93. Cambiasso MJ, Colombo JA, Carrer HF. Differential effect of oestradiol and astroglia-conditioned media on the growth of hypothalamic neurons from male and female rat brains. Eur J Neurosci. (2000) 12:2291-8. doi: 10.1046/j.1460-9568.2000.00120.x

94. Pansiot J, Mairesse J, Baud O. Protecting the developing brain by 17betaestradiol. Oncotarget. (2017) 8:12544-5. doi: 10.18632/oncotarget.14819

95. Berkane N, Liere P, Oudinet JP, Hertig A, Lefevre G, Pluchino N, et al. From pregnancy to preeclampsia: a key role for estrogens. Endocr Rev. (2017) 38:123-44. doi: 10.1210/er.2016-1065

96. Beltrand J, Verkauskiene R, Nicolescu R, Sibony O, Gaucherand P, Chevenne $\mathrm{D}$, et al. Adaptive changes in neonatal hormonal and metabolic profiles induced by fetal growth restriction. J Clin Endocrinol Metab. (2008) 93:402732. doi: 10.1210/jc.2008-0562

97. Gluckman PD. Clinical review 68: the endocrine regulation of fetal growth in late gestation: the role of insulin-like growth factors. J Clin Endocrinol Metab. (1995) 80:1047-50.

98. Boucher J, Charalambous M, Zarse K, Mori MA, Kleinridders A, Ristow $\mathrm{M}$, et al. Insulin and insulin-like growth factor 1 receptors are required for normal expression of imprinted genes. Proc Natl Acad Sci USA. (2014) 111:14512-7. doi: 10.1073/pnas.1415475111

99. Netchine I, Rossignol S, Azzi S, Brioude F, Le Bouc Y. Imprinted anomalies in fetal and childhood growth disorders: the model of RussellSilver and Beckwith-Wiedemann syndromes. Endocr Dev. (2012) 23:60-70. doi: 10.1159/000341750

100. Leger J, Oury JF, Noel M, Baron S, Benali K, Blot P, et al. Growth factors and intrauterine growth retardation. I. Serum growth hormone, insulin-like growth factor (IGF)-I, IGF-II, and IGF binding protein 3 levels in normally grown and growth-retarded human fetuses during the second half of gestation. Pediatr Res. (1996) 40:94-100. doi: 10.1203/00006450-199607000-00017

101. Leger J, Noel M, Limal JM, Czernichow P. Growth factors and intrauterine growth retardation. II. Serum growth hormone, insulin-like growth factor (IGF) I, and IGF-binding protein 3 levels in children with intrauterine growth retardation compared with normal control subjects: prospective study from birth to two years of age. Study Group of IUGR. Pediatr Res. (1996) 40:101-7. doi: 10.1203/00006450-199607000-00018

102. Godfrey KM, Hales CN, Osmond C, Barker DJ, Taylor KP. Relation of cord plasma concentrations of proinsulin, 32-33 split proinsulin, insulin and C-peptide to placental weight and the baby's size and proportions at birth. Early Hum Dev. (1996) 46:129-40. doi: 10.1016/0378-3782(96)0 $1752-5$
103. Gicquel C, Le Bouc Y. Hormonal regulation of fetal growth. Horm Res. (2006) 65(Suppl 3):28-33. doi: 10.1159/0000 91503

104. Freemark M. Regulation of maternal metabolism by pituitary and placental hormones: roles in fetal development and metabolic programming. Horm Res. (2006) 65(Suppl 3):41-9. doi: 10.1159/000091505

105. McIntyre HD, Zeck W, Russell A. Placental growth hormone, fetal growth and the IGF axis in normal and diabetic pregnancy. Curr Diabetes Rev. (2009) 5:185-9. doi: 10.2174/157339909788920947

106. Zeitlin J, Ancel PY, Saurel-Cubizolles MJ, Papiernik E. The relationship between intrauterine growth restriction and preterm delivery: an empirical approach using data from a European case-control study. BJOG. (2000) 107:750-8. doi: 10.1111/j.1471-0528.2000.tb13336.x

107. Dyer AH, Vahdatpour C, Sanfeliu A, Tropea D. The role of Insulin-Like Growth Factor 1 (IGF-1) in brain development, maturation and neuroplasticity. Neuroscience. (2016) 325:89-99. doi: 10.1016/j.neuroscience.2016.03.056

108. Mattson MP. Glutamate and neurotrophic factors in neuronal plasticity and disease. Ann N Y Acad Sci. (2008) 1144:97-112. doi: 10.1196/annals.1418.005

109. Shcheglovitov A, Shcheglovitova O, Yazawa M, Portmann T, Shu R, Sebastiano V, et al. SHANK3 and IGF1 restore synaptic deficits in neurons from 22q13 deletion syndrome patients. Nature. (2013) 503:267-71. doi: $10.1038 /$ nature 12618

110. Labandeira-Garcia JL, Costa-Besada MA, Labandeira CM, Villar-Cheda B, Rodriguez-Perez AI. Insulin-like growth factor-1 and neuroinflammation. Front Aging Neurosci. (2017) 9:365. doi: 10.3389/fnagi.2017.00365

111. Fernandez AM, Torres-Aleman I. The many faces of insulin-like peptide signalling in the brain. Nat Rev Neurosci. (2012) 13:225-39. doi: 10.1038/nrn3209

112. Park SE, Lawson M, Dantzer R, Kelley KW, McCusker RH. Insulin-like growth factor-I peptides act centrally to decrease depression-like behavior of mice treated intraperitoneally with lipopolysaccharide. J Neuroinflamm. (2011) 8:179. doi: 10.1186/1742-2094-8-179

113. Tien LT, Lee YJ, Pang Y, Lu S, Lee JW, Tseng CH, et al. Neuroprotective effects of intranasal IGF-1 against neonatal lipopolysaccharide-induced neurobehavioral deficits and neuronal inflammation in the substantia nigra and locus coeruleus of juvenile rats. Dev Neurosci. (2017) 39:443-59. doi: 10.1159/000477898

114. Pang Y, Zheng B, Campbell LR, Fan LW, Cai Z, Rhodes PG. IGF-1 can either protect against or increase LPS-induced damage in the developing rat brain. Pediatr Res. (2010) 67:579-84. doi: 10.1203/PDR.0b013e3181dc240f

115. Cai Z, Fan LW, Lin S, Pang Y, Rhodes PG. Intranasal administration of insulin-like growth factor-1 protects against lipopolysaccharide-induced injury in the developing rat brain. Neuroscience. (2011) 194:195-207. doi: 10.1016/j.neuroscience.2011.08.003

116. Lin S, Fan LW, Rhodes PG, Cai Z. Intranasal administration of IGF-1 attenuates hypoxic-ischemic brain injury in neonatal rats. Exp Neurol. (2009) 217:361-70. doi: 10.1016/j.expneurol.2009.03.021

117. Wood TL, Loladze V, Altieri S, Gangoli N, Levison SW, Brywe KG, et al. Delayed IGF-1 administration rescues oligodendrocyte progenitors from glutamate-induced cell death and hypoxic-ischemic brain damage. Dev Neurosci. (2007) 29:302-10. doi: 10.1159/000105471

118. Lopes C, Ribeiro M, Duarte AI, Humbert S, Saudou F, Pereira de Almeida L, et al. IGF-1 intranasal administration rescues Huntington's disease phenotypes in YAC128 mice. Mol Neurobiol. (2014) 49:1126-42. doi: 10.1007/s12035-013-8585-5

119. Ribeiro M, Rosenstock TR, Oliveira AM, Oliveira CR, Rego AC. Insulin and IGF-1 improve mitochondrial function in a PI-3K/Akt-dependent manner and reduce mitochondrial generation of reactive oxygen species in Huntington's disease knock-in striatal cells. Free Radic Biol Med. (2014) 74:129-44. doi: 10.1016/j.freeradbiomed.2014.06.023

120. Meijer WJ, Verloove-Vanhorick SP, Brand R, van den Brande JL. Transient hypothyroxinaemia associated with developmental delay in very preterm infants. Arch Dis Child. (1992) 67:944-7. doi: 10.1136/adc.67. 7.944

121. Den Ouden AL, Kok JH, Verkerk PH, Brand R, Verloove-Vanhorick SP. The relation between neonatal thyroxine levels and neurodevelopmental outcome at age 5 and 9 years in a national cohort of very preterm 
and/or very low birth weight infants. Pediatr Res. (1996) 39:142-5. doi: 10.1203/00006450-199601000-00021

122. Leviton A, Paneth N, Reuss ML, Susser M, Allred EN, Dammann O, et al. Hypothyroxinemia of prematurity and the risk of cerebral white matter damage. J Pediatr. (1999) 134:706-11. doi: 10.1016/S0022-3476(99) 70285-4

123. Delahunty C, Falconer S, Hume R, Jackson L, Midgley P, Mirfield $\mathrm{M}$, et al. Levels of neonatal thyroid hormone in preterm infants and neurodevelopmental outcome at $51 / 2$ years: millennium cohort study. J Clin Endocrinol Metab. (2010) 95:4898-908. doi: 10.1210/jc. 2010-0743

124. Ghassabian A, Bongers-Schokking JJ, Henrichs J, Jaddoe VW, Visser TJ, Visser W, et al. Maternal thyroid function during pregnancy and behavioral problems in the offspring: the generation R study. Pediatr Res. (2011) 69:454-9. doi: 10.1203/PDR.0b013e3182125b0c

125. Fisher DA. Thyroid system immaturities in very low birth weight premature infants. Semin Perinatol. (2008) 32:387-97. doi: 10.1053/j.semperi.2008.09.003

126. Kanike N, Davis A, Shekhawat PS. Transient hypothyroidism in the newborn: to treat or not to treat. Transl Pediatr. (2017) 6:349-58. doi: $10.21037 /$ tp. 2017.09 .07

127. Maynard SE, Min JY, Merchan J, Lim KH, Li J, Mondal S, et al. Excess placental soluble fms-like tyrosine kinase 1 (sFlt1) may contribute to endothelial dysfunction, hypertension, and proteinuria in preeclampsia. J Clin Invest. (2003) 111:649-58. doi: 10.1172/JCI 17189

128. Levine RJ, Maynard SE, Qian C, Lim KH, England LJ, Yu KF, et al. Circulating angiogenic factors and the risk of preeclampsia. $N$ Engl J Med. (2004) 350:672-83. doi: 10.1056/NEJMoa0 31884

129. Kendall RL, Thomas KA. Inhibition of vascular endothelial cell growth factor activity by an endogenously encoded soluble receptor. Proc Natl Acad Sci USA. (1993) 90:10705-9. doi: 10.1073/pnas.90.22.10705

130. Koga K, Osuga Y, Tajima T, Hirota Y, Igarashi T, Fujii T, et al. Elevated serum soluble fms-like tyrosine kinase 1 (sFlt1) level in women with hydatidiform mole. Fertil Steril. (2010) 94:305-8. doi: 10.1016/j.fertnstert.2009. 02.015

131. Savvidou MD, Yu CK, Harland LC, Hingorani AD, Nicolaides KH. Maternal serum concentration of soluble fms-like tyrosine kinase 1 and vascular endothelial growth factor in women with abnormal uterine artery Doppler and in those with fetal growth restriction. Am J Obstet Gynecol. (2006) 195:1668-73. doi: 10.1016/j.ajog.2006. 03.065

132. Di Martino D, Cetin I, Frusca T, Ferrazzi E, Fuse F, Gervasi MT, et al. Italian Advisory Board: sFlt-1/PlGF ratio and preeclampsia, state of the art and developments in diagnostic, therapeutic and clinical management. Eur J Obstet Gynecol Reprod Biol. (2016) 206:70-3. doi: 10.1016/j.ejogrb.2016.08.036

133. Levine RJ, Vatten LJ, Horowitz GL, Qian C, Romundstad PR, Yu KF, et al. Pre-eclampsia, soluble fms-like tyrosine kinase 1 , and the risk of reduced thyroid function: nested case-control and population based study. BMJ. (2009) 339:b4336. doi: 10.1136/bmj.b4336

134. Mannisto T, Karumanchi SA, Pouta A, Vaarasmaki M, Mendola P, Miettola S, et al. Preeclampsia, gestational hypertension and subsequent hypothyroidism. Pregnancy Hypertens. (2013) 3:21-7. doi: 10.1016/j.preghy.2012.09.001

135. Kamba T, Tam BY, Hashizume H, Haskell A, Sennino B, Mancuso MR, et al. VEGF-dependent plasticity of fenestrated capillaries in the normal adult microvasculature. Am J Physiol Heart Circ Physiol. (2006) 290:H560-76. doi: 10.1152/ajpheart.00133.2005

136. Voller SB, Chock S, Ernst LM, Su E, Liu X, Farrow KN, et al. Cord blood biomarkers of vascular endothelial growth (VEGF and sFlt-1) and postnatal growth: a preterm birth cohort study. Early Hum Dev. (2014) 90:195-200. doi: 10.1016/j.earlhumdev.2014.01.003

137. Korevaar TI, Steegers EA, Schalekamp-Timmermans S, Ligthart S, de Rijke YB, Visser WE, et al. Soluble Flt1 and placental growth factor are novel determinants of newborn thyroid (dys)function: the generation R study. $J$ Clin Endocrinol Metab. (2014) 99:E1627-34. doi: 10.1210/jc.2014-1884

138. Thorpe-Beeston JG, Nicolaides KH, McGregor AM. Fetal thyroid function. Thyroid. (1992) 2:207-17. doi: 10.1089/thy.1992.2.207

139. Mahajan SD, Aalinkeel R, Singh S, Shah P, Gupta N, Kochupillai $\mathrm{N}$. Endocrine regulation in asymmetric intrauterine fetal growth retardation. J Matern Fetal Neonatal Med. (2006) 19:615-23. doi: 10.1080/14767050600799901

140. Nieto-Diaz A, Villar J, Matorras-Weinig R, Valenzuela-Ruiz P. Intrauterine growth retardation at term: association between anthropometric and endocrine parameters. Acta Obstet Gynecol Scand. (1996) 75:127-31. doi: $10.3109 / 00016349609033303$

141. Fetter WP, Waals-Van de Wal CM, Van Eyck J, Samson G, BongersSchokking JJ. Thyroid hormone concentrations in preterm infants born to pre-eclamptic women with placental insufficiency. Acta Paediatr. (1998) 87:186-90. doi: 10.1111/j.1651-2227.1998.tb00973.x

142. Ryckman KK, Spracklen CN, Dagle JM, Murray JC. Maternal factors and complications of preterm birth associated with neonatal thyroid stimulating hormone. J Pediatr Endocrinol Metab. (2014) 27:929-38. doi: 10.1515/jpem-2013-0366

143. Miller SL, Huppi PS, Mallard C. The consequences of fetal growth restriction on brain structure and neurodevelopmental outcome. J Physiol. (2016) 594:807-23. doi: 10.1113/JP271402

Conflict of Interest Statement: The authors declare that the research was conducted in the absence of any commercial or financial relationships that could be construed as a potential conflict of interest.

Copyright $\odot 2019$ Baud and Berkane. This is an open-access article distributed under the terms of the Creative Commons Attribution License (CC BY). The use, distribution or reproduction in other forums is permitted, provided the original author(s) and the copyright owner(s) are credited and that the original publication in this journal is cited, in accordance with accepted academic practice. No use, distribution or reproduction is permitted which does not comply with these terms. 